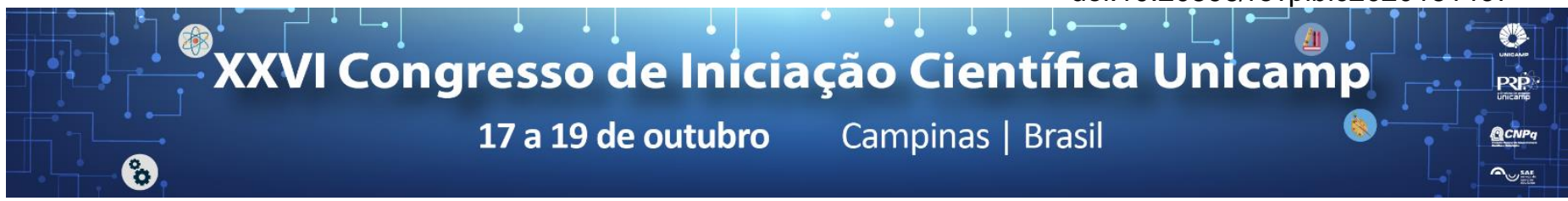

\title{
Ferramentas de software e hardware livre para a acessibilidade musical do deficiente visual.
}

Alunas: Caroline Alves do Nascimento - caroline-alvesnas12@hotmail.com, Lorenna Rodrigues dos Santos rlorenna074@gmail.com.br, Raissa Ribeiro Pereira - raissaribeiro.r2@gmail.com

Colaboradores: Bianca Ruzzene Andréo - biaandreo@hotmail.com, Fernanda Alves Landim - felandim@unicamp.br

Coordenação: Prof. Dr. José Fornari - tutifornari@gmail.com, Prof. Dr. Vilson Zattera - vzattera@uol.com.br

Resumo: O projeto visa criar recursos de inclusão para músicos deficientes visuais através de softwares e hardwares livres para a acessibilidade em análise, composição e performance musical.

Palavras-chave: Acessibilidade musical; Deficiência visual; Software livre

\section{Introdução}

Este projeto foi desenvolvido no Laboratório de Acessibilidade (LAB) da Diretoria de Difusão da Informação da Biblioteca Central Cesar Lattes (BCCL)UNICAMP. Seu objetivo foi produzir materiais didáticos e iniciativas que auxiliassem os usuários com deficiência visual ao acesso à informação musical e assim garantir sua participação plena na vida acadêmica e musical. Este projeto visou conscientizar os alunos do ensino médio dos problemas enfrentados por músicos com deficiência visual, assim utilizando e desenvolvendo programas de apoio aos músicos deficientes visuais (MDV) nos processos de criação, análise e desenvolvimento musical.

\section{Resultados e Discussão}

O procedimento realizado para garantir a acessibilidade musical aos MDV, foi através de softwares leitores de tela, como o Jaws e o NVDA. As alunas participaram de aulas de música dos alunos da graduação no Instituto de Artes, para aprenderem noções de notação musical e assim poderem trabalhar com os songbooks (livro de tablaturas e letras de músicas cifradas) na conversão das letras e cifras musicais através de um programa de conversão criado no LAB. Foram utilizados softwares livres para edição e análise musical, como o Audacity e o Sonic Visualizer, o que permitiu às alunas se familiarizarem com 0 uso destes e assim conscientizarem-se das dificuldades enfrentadas pelos MDV.

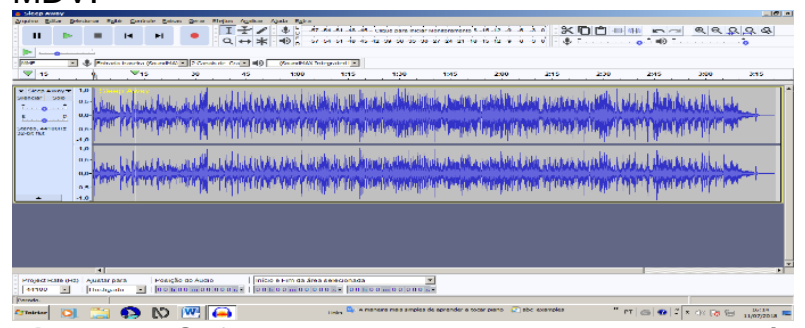

Figura 1. Software Audacity com o arquivo de áudio da música "Sleep Away".

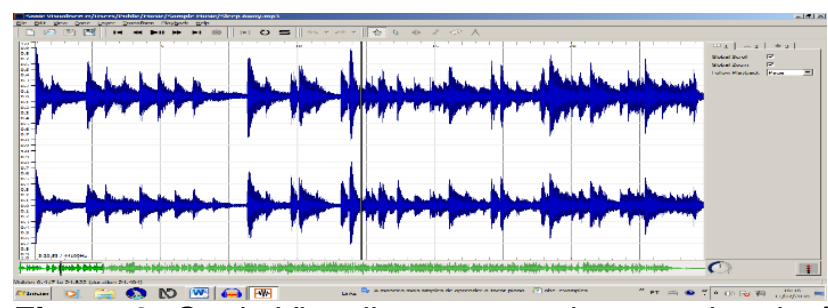

Figura 2. Sonic Visualizer mostrando o arquivo de áudio da música "Sleep Away".

\section{Conclusões}

Conclui-se que o projeto proporcionou às alunas um maior conhecimento e compreensão acerca da importância da acessibilidade musical para os MDV. É necessário que a sociedade saiba a importância da inclusão dos deficientes na sociedade e de como isto pode ser alcançado. O principal objetivo dos métodos e programas aqui desenvolvidos foi permitir que um músico com deficiência visual possa um dia criar e editar sozinho músicas num computador, de uma forma mais acessível.

\section{Agradecimentos}

As alunas agradecem aos funcionários do LAB/UNICAMP, aos colaboradores e aos coordenadores deste projeto, pela oportunidade de participarem neste trabalho voluntário, o que as ajudou a melhor entender a importância da acessibilidade e inclusão na vida musical e acadêmica das pessoas com deficiência visual.

PENTEADO, Antonio Fernando da Cunha. Acessibilidade recíproca no diálogo musical entre violonistas cegos e videntes. $114 \mathrm{f}$. Dissertação- Instituto de Artes, Universidade Estadual de Campinas, Campinas.

VASCONCELLOS, Renato de. A partitura cifrada e os descaminhos dos "Fake books". 2017. 285 f. Tese- Instituto de Artes, Universidade Estadual de Campinas, Campinas. 